\title{
KERAGAAN PERTUMBUHAN DAN PRODUKSI BAWANG MERAH (Allium ascalonicum L.) DENGAN PENGATURAN PUPUK KANDANG
}

\section{Ida Setya Wahyu Atmaja, Mohammad Subkhi dan Amran Jaenudin}

Universitas Swadaya Gunung Jati, Cirebon, Jawa Barat. Indonesia

Email: iedaatmaja@gmail.com,mohammadsubhki55@gmail.com dan amranjaenudin57@gmail.com

\section{Abstract}

Shallot is horticulture commodities with high economic values. Need some efforts to improve growth and production of shallot, such organic matter added. Through this research analyze how the performance of growth and shallot production cultivar Bauji with chicken manure dosses added. This research used randomized block design, three treatment and four replies. Dosses of chicken manure is 0,20 and 40 ton $\mathrm{ha}^{-1}$. This research showed that chicken manure added effected to plant high in 14 days after planting (DAP), number of leave 14 and 21 DAP. But, not effected significantly to production of shallot. Soil $\mathrm{pH}$ and nutrient content effected to absorption of chicken manure fertilizer.

Keywords: chicken manure, fertilizer, shallot

\begin{abstract}
Abstrak
Tanaman bawang merah merupakan komoditas hortikultura yang memiliki nilai ekonomi yang strategis. Untuk menunjang pertumbuhan dan meningkatkan produksi tanaman bawang merah maka diperlukan berbagai upaya, diantaranya penambahan bahan organik sebagai pupuk. Tujuan dari penelitian ini adalah untuk menganalisis keragaan pertumbuhan dan produksi tanaman bawang merah kultivar Bauji dengan pengaturan dosis pupuk kandang ayam. Penelitian ini menggunakan rancangan acak kelompok dengan tiga perlakuan dosis pupuk kandang $(0,20$ dan 40 ton/ha) dan setiap perlakuan diulang empat kali. Hasil percobaan menunjukkan bahwa penggunaan dosis pupuk kandang ayam memberikan pengaruh nyata terhadap tinggi tanaman pada 14 HST, jumlah daun pada 14 dan 21 HST. Sedangkan pada komponen hasil pengaturan dosis pupuk kandang ayam tidak berpengaruh nyata pada bobot basah dan bobot kering per petak. $\mathrm{pH}$ dan kandungan hara tanah berpengaruh terhadap penyerapan pupuk kandang yang diberikan
\end{abstract}

Kata kunci: bahan organik, bawang merah, pupuk kandang ayam.

Coresponden Author

Email: iedaatmaja@gmail.com Artikel dengan akses terbuka dibawah lisensi 


\section{Pendahuluan}

Bawang merah (Allium ascalonicum L.) merupakan komoditas hortikultura yang memiliki potensi ekonomi yang tinggi untuk dikembangkan. Tanaman ini mampu hidup subur baik pada daerah tropis maupun subtropis, salah satunya adalah di Indonesia (Sihombing, 2018). Sebagai komoditas unggulan tanaman ini banyak dibudidayakan terutama di sentra produksi bawang merah yang tersebar di seluruh wilayah Indonesia termasuk Kabupaten Cirebon. Memiliki hubungan erat dengan bawang Bombay (Allium cepa L.) tanaman bawang merah memiliki manfaat baik untuk kesehatan karena kandungan senyawa antioksidan quercetin (Sari, 2016), energy, mineral dan sejumlah vitamin (Waluyo \& Sinaga, 2015). Selain itu bawang merah juga merupakan bahan dasar masakan yang memberikan aroma yang khas.

Walaupun bawang merah menjadi komoditas yang bernilai ekonomi tinggi akan tetapi produksi nasional cenderung mengalami fluktuasi. Data dari Badan Pusat Statistika menunjukkan bahwa pada tahun 2014-2017 produktivitas nasional bawang merah mengalami penurunan yaitu 10,22 ton/ha menjadi 9, 29 ton/ha. Kondisi tanah dan penggunaan pupuk merupakan dua hal yang memiliki andil dalam penurunan produktivitas bawang merah (Afrilliana, Darmawati, \& Sumarsono, 2017). Pupuk merupakan salah satu faktor produksi yang memiliki peran sebagai penambah unsur hara bagi tanaman. Pupuk dapat diberikan kepada tanaman baik sebagai pupuk anorganik maupun pupuk organik. Salah satu cara yang dapat dijadikan alternatif adalah penggunaan bahan organik yang berasal dari pupuk kandang sebagai penambah unsur hara bagi tanaman.

Pupuk kandang ayam merupakan pupuk yang berasal dari kotoran/feses/urine ayam. Pupuk kandang ayam kering mengandung N 2,59\%, P 3,09\%, K 2,46\%, Ca 12,66\%, Mg 0,91\%, Na 0,69\%, Fe 1.758 ppm, Mn 572 ppm, Zn 742 ppm, Cu 80 ppm, sehingga dalam 1 ton pupuk kandang ayam mengandung 65,8 kg N, 13,7 kg P, dan 12,8 kg K (Sulasmi, Safruddin, \& Mawarni, 2020). Berdasarkan kandungan hara yang dimiliki pupuk kandang ayam, maka bahan ini memiliki potensi untuk dikembangkan sebagai pupuk organik yang dapat digunakan sebagai penambah hara bagi tanaman bawang merah. Menurut Asri, et al (2019) kelebihan dari pupuk kandang bagi tanaman bawang merah adalah kandungan unsur hara mikro yang lebih tersedia dibandingkan pupuk anorganik, serta mampu mencegah munculnya ledakan sub-hara lain yang berpotensi menyebabkan terjadinya keracunan bagi tanaman. Selain sebagai penambah hara pupuk kandang juga memiliki peran dalam perbaikan sifat fisik dan biologi tanah. Penambahan pupuk kandang dapat memperbaiki struktur tanah sehingga menciptakan kondisi yang ideal bagi pertumbuhan dan perkembangan akar tanaman. Kandungan C-organik yang cukup pada pupuk kandang mampu menggemburkan tanah sehingga dapat memacu penyerapan hara yang maksimal

Bauji merupakan salah satu kultivar lokal tanaman bawang merah yang tidak banyak dibudidayakan di sentra produksi bawang merah di wilayah Cirebon. Umumnya petani lokal banyak menggunakan kultivar lain secara turun temurun, diantaranya kultivar Bima. Melalui penelitian ini di uji cobakan penambahan pupuk kandang pada budidaya 
tanaman bawang merah lokal kultivar Bauji. Tujuan penelitian ini adalah untuk mengetahui bagaimana keragaan pertumbuhan dan produksi bawang merah (Allium ascalonicum L.) kultivar Bauji dengan adanya pengaturan dosis pupuk kandang ayam.

\section{Metode Penelitian}

Percobaan dilaksanakan di Desa Suranenggala Kidul Kecamatan Suranenggala Kabupaten Cirebon pada bulan April-Juni 2019. Bahan yang digunakan dalam percobaan ini adalah umbi bibit bawang merah (Allium ascalonicum L.) kultivar Bauji, pupuk kandang ayam, pupuk anorganik (NPK Phonska, Urea, ZA, SP-36, dan KCl), EM4, Furadan 3G, Nordox 56 WP, Dithane M-45, Decis 25 EC, Lanate 25 WP. Bibit yang digunakan berasal dari umbi yang telah disimpan 2-3 bulan setelah panen. Percobaan dilakukan dengan menggunakan Rancangan Acak Kelompok (RAK) dengan tiga perlakuan dan diulang empat kali. Perlakuan yang diuji adalah dosis pupuk kandang ayam (0,20, dan 40 ton/ha).

Pupuk kandang ayam diaplikasikan 14 hari sebelum tanam dengan cara ditabur sesuai dengan perlakukan dan dicampur dengan tanah pada petak percobaan untuk mempercepat proses mineralisasi dan membuang gas-gas yang berbahaya dalam tanah. Pupuk anorganik juga diberikan sesuai dengan rekomendasi, yaitu NPK Phonska 250 $\mathrm{kg} / \mathrm{ha}$, SP-36 $50 \mathrm{~kg} / \mathrm{ha}$ dan $\mathrm{KCl} 30 \mathrm{~kg} / \mathrm{ha}$ diberikan pada saat 7 hari sebelum tanam (sebagai pupuk dasar). Pupuk susulan pertama yang digunakan adalah pupuk ZA 400 $\mathrm{kg} / \mathrm{ha}$ diberikan pada saat 10 hari setelah tanam (HST) kemudian pupuk susulan kedua berupa pupuk Urea $180 \mathrm{~kg} / \mathrm{ha}$ pada $30 \mathrm{HST}$. Sebelum penanaman ujung umbi dipotong $1 / 4$ bagian dan diberikan perlakukan fungisida. Bibit ditanam pada petak percobaan dengan jarak tanam $20 \mathrm{~cm} \times 15 \mathrm{~cm}$. Pengamatan dilakukan pada enam tanaman sampel pada setiap petak percobaan. Pengamatan mencakup komponen vegetatif dan generatif tanaman, meliputi tinggi tanaman, jumlah daun, bobot segar dan bobot kering per petak. Pengamatan vegetatif dilakukan pada umur 14, 21, 28, 35 HST sedangkan pengamatan generatif dilakukan pada saat panen.

\section{Hasil dan Pembahasan}

\section{A. Tinggi Tanaman}

Tinggi tanaman menunjukkan rata-rata tinggi tanaman yang diukur dari pangkal umbi yang berbatasan dengan permukaan tanah sampai ujung daun tanaman tertinggi. Hasil analisis statistik menunjukkan bahwa pengaturan dosis pupuk kandang ayam berpengaruh nyata pada rata-rata tinggi tanaman pada 14 HST (Tabel 1).

\section{Tabel 1}

Rata-rata Tinggi Tanaman 14, 21, 28 dan 35 HST pada Beberapa Dosis Pupuk Kandang

\begin{tabular}{lllll}
\hline & \multicolumn{4}{c}{ Rata-rata Tinggi Tanaman $(\mathrm{cm})$} \\
\cline { 2 - 5 } Dosis Pupuk Kandang & $14 \mathrm{HST}$ & $21 \mathrm{HST}$ & $28 \mathrm{HST}$ & $35 \mathrm{HST}$ \\
\hline 0 ton/ha & $13,61 \mathrm{a}$ & $19,44 \mathrm{a}$ & $20,51 \mathrm{a}$ & $21,48 \mathrm{a}$ \\
20 ton/ha & $14,19 \mathrm{~b}$ & $20,25 \mathrm{a}$ & $22,13 \mathrm{a}$ & $23,10 \mathrm{a}$ \\
\hline
\end{tabular}




\begin{tabular}{lllll}
\hline 40 ton/ha & 13,34 a & 19,02 a & 21,95 a & 22,63 a \\
\hline
\end{tabular}

Keterangan: Angka rata-rata disertai huruf yang berbeda pada kolom yang sama menunjukkan perbedaan yang nyata menurut Uji LSR pada taraf 5\%.

Berdasarkan data pada Tabel 1 diketahui bahwa pengaturan dosis pupuk kandang ayam berpenagruh pada umur 14 HST. Perlakukan pemberian pupuk kandang ayam dengan dosis 20 ton/ha memiliki rata-rata tinggi tanaman tertinggi, yaitu 14,19 cm. Hal ini disebabkan karena tanaman mendapatkan unsur hara dalam tanah baik melalui pemberian pupuk kandang maupun pupuk anorganik sebagai pupuk dasar yang pada akhirnya berpengaruh terhadap tinggi tanaman. Sejalan dengan pernyataan Hayati, et al (2011) menyatakan bahwa salah satu faktor yang mempengaruhi pertumbuhan awal tanaman adalah kecukupan unsur hara di dalam tanah. Sedangkan pada umur 21, 28 dan 35 HST pengaturan dosis pupuk kandang ayam tidak berpengaruh nyata pada rata-rata tinggi tanaman.

Selain menyumbang unsur hara bagi tanaman, pupuk kandang sebagai bahan organik tanah berperan dalam memperbaiki struktur tanah sehingga memberikan kondisi tanah yang baik untuk perkembangan akar yang berdampak pada penyerapan air dan unsur hara. Pupuk kandang ayam mampu memperbaiki sifat tanah baik fisk, kimia dan biologi tanah melalui perbaikan aerasi dan daya pegang tanah terhadap air (water holding capacity) sehingga akar tanaman dapat tumbuh dan mampu menyerap unsur hara dengan optimal (Sutedjo, 2010).

\section{B. Jumlah Daun}

Daun merupakan organ yang sangat penting bagi tanaman karena merupak tempat terjadinya fotosintesa. Fotosintat yang dihasilkan ditentukan oleh banyaknya daun pada tanaman. Hasil analisis ststistik pengaturan dosis pupuk kandang terhadap jumlah daun disajikan pada Tabel 2.

\section{Tabel 2}

Rata-rata Jumlah Daun 14, 21, 28 dan 35 HST pada Beberapa Dosis Pupuk Kandang

\begin{tabular}{lllll}
\hline & \multicolumn{4}{c}{ Rata-rata Jumlah Daun (Helai) } \\
\cline { 2 - 5 } Dosis Pupuk Kandang & $14 \mathrm{HST}$ & $21 \mathrm{HST}$ & $28 \mathrm{HST}$ & $35 \mathrm{HST}$ \\
\hline 0 ton/ha & $14,62 \mathrm{a}$ & $15,37 \mathrm{ab}$ & $16,08 \mathrm{a}$ & $16,12 \mathrm{a}$ \\
20 ton/ha & $14,91 \mathrm{~b}$ & $15,79 \mathrm{~b}$ & $16,12 \mathrm{a}$ & $16,79 \mathrm{a}$ \\
40 ton/ha & $13,87 \mathrm{a}$ & $14,37 \mathrm{a}$ & $15,54 \mathrm{a}$ & $15,92 \mathrm{a}$ \\
\hline
\end{tabular}

Keterangan: Angka rata-rata disertai huruf yang berbeda pada kolom yang sama menunjukkan perbedaan yang nyata menurut Uji LSR pada taraf 5\%.

Data pada Tabel 2 menunjukkan bahwa pengaturan dosis pupuk kandang berpengaruh nyata terhadap rata-rata jumlah daun pada umur pengamatan 14 dan 21 HST. Pupuk kandang dengan dosis 20 ton/ha memiliki rata-rata jumlah daun tertinggi dibandingkan perlakuan lainnya, yaitu sebesar 14,91 pada 14 HST dan 15,79 pada 21 HST. Hal ini menunjukkan bahwa pemberian pupuk kandang sebesar 20 ton/ha mampu mencukupi kebutuhan tanaman untuk memproduksi organ baru yaitu daun. 
Sedangkan pada umur pengamatan 28 dan 32 HST pengaturan dosis pupuk kandang tidak berpengaruh nyata terhadap rata-rata jumlah daun. Hal ini disebabkan karena pada umur pengamatan 28 HST tanaman bawang merah mulai memasuki fase pembentukan umbi sehingga laju pertumbuhan daun mengalami penurunan. Menurut Samadi \& Cahyono (2005) pembentukan daun akan mengalami hambatan ketika tanaman mulai memasuki fase generatif diantaranya adalah pembentukan umbi.

Pupuk kandang ayam mengandung sejumlah hara termasuk unsur nitrogen yang dibutuhkan oleh tanaman. Menurut Damanik, et al (2010) kandungan Nitrogen pada pupuk kandang ayam tiga kali lebih banyak dibanding pupuk kandang lainnya. Nitrogen merupakan molekul penyusun klorofil daun yang bertanggung jawab terhadap proses fotosintesis (Latarang \& Syakur, 2006). Nitrogen juga merupakan bahan dasar pembentukan asam amino yang diperlukan dalam proses metabolisme tanaman yang pada akhirnya mempengaruhi pertumbuhan daun (Musrif dan Sriasih, 2019). Pupuk kandang ayam memiliki kandungan hara yang lebih tinggi karena bagian padatan bercampur dengan bagian cair/urine (Roidah, 2013). Pupuk kandang ayam terdekomposisi lebih cepat sehingga unsur hara yang tersedia lebih cepat tersedia dan diserap oleh tanaman (Hartatik \& Widowati, 2010). Hal ini sangat berpengaruh terhadap pertumbuhan tanaman, termasuk pertambahan tinggi tanaman dan jumlah daun.

\section{Bobot Basah dan Bobot Kering Umbi Bawang Merah}

Berdasarkan hasil analisis statistik menunjukkan bahwa pengaturan dosis pupuk kandang ayam tidak berpengaruh nyata terhadap bobot basah dan bobot kering umbi per petak. Hasil analisis bobot basah dan bobot kering umbi bawang merah disajikan pada Tabel 3.

Table 3

Bobot Basah dan Bobot Kering Umbi Bawang Merah per Petak

\begin{tabular}{lcc} 
Dosis Pupuk Kandang & $\begin{array}{c}\text { Bobot Basah per Petak } \\
\text { (gr) }\end{array}$ & $\begin{array}{c}\text { Bobot Kering per } \\
\text { Petak (gr) }\end{array}$ \\
\hline 0 ton/ha & $1.314 \mathrm{a}$ & $1.059 \mathrm{a}$ \\
20 ton/ha & $2.084 \mathrm{a}$ & $1.620 \mathrm{a}$ \\
40 ton/ha & $1.112 \mathrm{a}$ & $851 \mathrm{a}$ \\
\hline
\end{tabular}

Keterangan : Angka rata-rata disertai huruf yang berbeda pada kolom yang sama menunjukkan perbedaan yang nyata menurut Uji LSR pada taraf $5 \%$.

Berdasarkan Tabel 3 perlakuan pengaturan dosis pupuk kandang ayam, tidak berpengaruh nyata terhadap bobot basah dan bobot kering umbi per petak. Tanaman bawang merah yang diberi pupuk kandang 20 ton/ha memiliki bobot basah per petak sebesar $2.084 \mathrm{gr} /$ petak atau setara dengan 10,42 ton/hektar dan bobot kering per petak sebesar $1.620 \mathrm{gr} /$ petak atau setara dengan 8,1 ton/hektar. Nilai tersebut masih jauh dari potensi produksi yaitu sebesar 14 ton/hektar umbi kering. 
Berdasarkan hasil analisis tanah diketahui bahwa lahan percobaan memiliki $\mathrm{pH}$ tanah 5,81 (agak masam) dan kandungan $\mathrm{P}_{2} \mathrm{O}_{5}$ tersedia sebesar 9,88 ppm (sangat rendah) dan $\mathrm{K}_{2} \mathrm{O}$ tersedia 62,66 ppm (rendah). Nilai $\mathrm{pH}$ yang optimal untuk penyerapan unsur hara, khususnya unsur hara makro adalah pada rentang $\mathrm{pH}$ netral (6-7). Agar pemupukan atau penyerapan unsur hara pada tanaman bawang merah optimal maka $\mathrm{pH}$ tanah diusahakan pada $\mathrm{pH} \geq 6$ Rendahnya nilai $\mathrm{pH}$ tanah diduga menyebabkan penyerapan unsur hara khususnya unsur fosfor menjadi tidak optimal. Fosfor dibutuhkan untuk pembentukan dan perkembangan umbi bawang merah (Jazilah \& Sunarto, 2007).

Selain fosfor, kalium juga merupakan unsur hara yang penting dalam pembentukan umbi bawang merah. Kalim berperan sebagai katalisator enzim dalam pembentukan asam amino, mambantu translokasi fotosintat yang dihasilkan dan mempengaruhi kualitas buah dan biji (Uke, Barus, \& Madauna, 2015). Tanaman umbi-umbian membutuhkan Kalium dalam jumlah banyak dibandingkan unsur lainnya (Sumiati \& Gunawan, 2007). Akan tetapi di dalam tanah kalium sering menjadi faktor pembatas bagi pertumbuhan tanaman, dikarenakan unsur kalium memiliki kepekaan yang tinggi terhadap pencucian (Uke et al., 2015). Selain memiliki sifat mudah tercusi, ketersediaan kalium dalam tanah juga dipengaruhi oleh $\mathrm{pH}$ tanah dan kejenuhan basa. Pada $\mathrm{pH}$ dan $\mathrm{KB}$ rendah maka unsur kalium akan mudah tercuci (Manurung \& Vindo, 2020)

\section{Kesimpulan}

Penambahan pupuk kandang ayam 20 ton/ha mampu meningkatkan pertumbuhan vegetatif tanaman, yaitu tinggi tanaman dan jumlah daun pada 14 dan 21 HST. Sedangkan pada komponen generatif penambahan pupuk kandang ayam 20 ton/ha belum mampu meningkatkan bobot basah dan bobot kering umbi bawang merah. Kondisi tanah yang meliputi $\mathrm{pH}$ dan kandungan hara tanah berpengaruh terhadap penyerapan pupuk kandang yang diberikan. 
Ida Setya Wahyu Atmaja, Mohammad Subkhi dan Amran Jaenudin

\section{BIBLIOGRAFI}

Afrilliana, Neli, Darmawati, Adriani, \& Sumarsono, Sumarsono. (2017). Pertumbuhan dan hasil panen Bawang Merah (Allium ascalonicum 1.) akibat penambahan pupuk $\mathrm{KCl}$ berbasis pupuk organik berbeda. Journal of Agro Complex, 1(3), 126-134.

Asri, B., Arma, Rahmawati, \& Riska, Riska. (2019). Respon Pertumbuhan Dan Produksi Varietas Bawang Merah (Allium Cepa L.) Terhadap Pemberian Pupuk Kandang. Agrominansia, 4(2), 167-175.

Damanik, M.Madjid B., Hasibuan, Bachtiar Effendi, Fauzi, Sarifuddin, \& Hanum, Hamidah. (2010). Kesuburan Tanah Dan Pemupukan. Universitas Sumatera Utara. Medan.

Hartatik, W., \& Widowati, L. R. (2010). Pupuk Kandang.[Manure]. Laporan Akhir Penelitian.

Hayati, Mardhiah, Hayati, Erita, \& Denni, Denni. (2011). Pengaruh Pupuk Organik Dan Anorganik Terhadap Pertumbuhan Beberapa Varietas Jagung Manis Di Lahan Tsunami. Jurnal Floratek, 6(1), 74-83.

Jazilah, S., \& Sunarto, Sunarto. (2007). Respon Tiga Varietas Bawang Merah Terhadap Dua Macam Pupuk Kandang dan Empat Dosis Pupuk Anorganik. Agrin, 11(1).

Latarang, Burhanudin, \& Syakur, Abdul. (2006). Pertumbuhan Dan Hasil Bawang Merah (Allium Ascalonicum L.) Pada Berbagai Dosis Pupuk Kandang. Agroland: Jurnal Ilmu-Ilmu Pertanian, 13(3).

Manurung, Agnes I., \& Vindo, Vindo. (2020). Pengaruh Dosis Dolomit Dan Pupuk Kalium Terhadap Pertumbuhan Dan Hasil Tanaman Bawangmerah (Alium ascalanicum L) Varietas Vietnam. Jurnal Agrotekda, 3(2), 103-116.

Musrif, Ni Luh Sriasih. (2019). Pengaruh Limbah Air Tahu dan Pupuk Kandang Ayam Terhadap Pertumbuhan dan Produksi Bawang Daun (Allium fistolosum L.). Jurnal Agriyan, 5(2).

Roidah, Ida Syamsu. (2013). Manfaat penggunaan pupuk organik untuk kesuburan tanah. Jurnal Bonorowo, 1(1), 30-43.

Samadi, Ir Budi, \& Cahyono, Ir Bambang. (2005). Bawang Merah, Intensifikasi Budi Daya. Jakarta: Kanisius.

Sari, Ayu Nirmala. (2016). Berbagai Tanaman Rempah Sebagai Sumber Antioksidan Alami. Elkawnie, 2(2), 203-212.

Sihombing, Parsaoran. (2018). Respon Pertumbuhan Dan Produksi Bawang Merah (Allium ascalonicum. L) Terhadap Pemberian Pupuk Kandang Ayam Dan Pupuk Npk. Jurnal Stindo Profesional, IV(4), 198-213. 
Keragaan Pertumbuhan dan Produksi Bawang Merah (Allium Ascalonicum L.) dengan Pengaturan Pupuk Kandang

Sulasmi, Sulasmi, Safruddin, Safruddin, \& Mawarni, Rita. (2020). Pengaruh Pemberian Pupuk Organik Cair (Poc) Top G2 Dan Pupuk Kandang Ayam Terhadap Pertumbuhan Dan Produksi Tanaman Bawang Merah (Allium ascalonicum L.). Bernas: Jurnal Penelitian Pertanian, 16(1), 103-111.

Sumiati, E., \& Gunawan, O. S. (2007). Aplikasi pupuk hayati mikoriza untuk meningkatkan efisiensi serapan unsur hara NPK serta pengaruhnya terhadap hasil dan kualitas umbi bawang merah. Jurnal Hortikultura, 17(1).

Sutedjo, M. M. (2010). Pupuk dan Cara Pemupukan. Cetakan-9. Jakarta: PT. Rineka Cipta.

Uke, H. Y., Barus, Henry, \& Madauna, Ichwan S. (2015). Pengaruh Ukuran Umbi Dan Dosis Kalium Terhadap Pertumbuhan Dan Hasil Produksi Bawang Merah (Allium Ascalonicum L.) Varietas Lembah Palu. Agrotekbis, 3(6).

Waluyo, Nurmalita, \& Sinaga, Rismawita. (2015). Bawang Merah Yang dirilis Oleh Balai Penelitian Tanaman Sayuran. Iptek Tanaman Sayuran, (5). 